\title{
Assessment of periodontal status in a group of patients and correlations with factors which favoring periodontal disease
}

\author{
Evaluarea statusului parodontal la un lot de pacienți și corelații \\ cu factorii favorizanți ai îmbolnăvirii parodontale
}

\author{
Cristina Vodiță ${ }^{1,2}$, Emanuel Alin Vodiță ${ }^{1,2}$, Costin Coman ${ }^{3}$, Raluca Monica Comăneanu ${ }^{1,3}$, \\ Doina Lucia Ghergic ${ }^{1,3}$, Laurența Lelia Mihai ${ }^{3}$ \\ ${ }^{1}$ Şcoala Doctorală - Domeniul Medicină Dentară, IOSUD „Titu Maiorescu“, Bucureşti, România \\ ${ }^{2}$ Clinica stomatologică „Dr. Vodiță“, Bucureşti, România \\ ${ }^{3}$ Facultatea de Medicină Dentară, Universitatea „Titu Maiorescu“, Bucureşti, România
}

\begin{abstract}
Objectives. The study aimed to assess the periodontal status of a group of patients and to highlight the correlations with factors favoring the occurrence and worsening of periodontal disease.

Material and method. The study was carried out within the „Dr. Vodiță“ Dental Clinic for a period of 2 years. The study group initially consisted of 266 patients who approached the Clinic for various dental reasons. We applied inclusion and exclusion criteria from the study to the initial group of patients. After applying the inclusion and exclusion criteria from the study, the final group of patients consisted of 205 patients of both sexes, aged between 18 and 76 years. The data were analyzed and statistically processed with the Microsoft Excel 2016 program.

Results. The study group consisted of 138 male patients and 67 female patients, including 5 bruxomaniacs, 12 oral respirators, 36 patients with malocclusions and 54 patients with reduced or extended edentulous partially prosthetic. The Loe and Silness gingival index and the papillary bleeding index had the majority value 1.

Discussions. In the present study, young patients were best represented. Cardiovascular diseases have an increased incidence among the group analyzed, $17.07 \%$ of patients said they live in stressful conditions and $47.32 \%$ of patients said they smoke.

Conclusions. Most patients in the present study were young adults with generalized forms of periodontal disease. The main reasons for presenting to the doctor were gingival bleeding and halitosis, which are signs of periodontal disease. Smoking, daily stress and cardiovascular diseases are factors involved in the appearance and evolution of periodontal disease.
\end{abstract}

Keywords: gingivitis, periodontitis, smoking, cardiovascular disease, stress

\section{REZUMAT}

Obiective. Studiul a avut drept scop evaluarea statusului parodontal a unui lot de pacienți și evidenţierea unor corelații cu factorii favorizanți ai apariției și agravării bolii parodontale.

Material şi metodă. Studiul s-a desfăşurat în cadrul Clinicii stomatologice „Dr. Vodiță“ pe o perioadă de 2 ani. Lotul de studiu a fost alcătuit inițial din 266 pacienți care s-au adresat clinicii din diferite motive stomatologice. La lotul inițial de pacienți, am aplicat criterii de includere şi de excludere din studiu. După aplicarea criteriilor de includere şi excludere din studiu, lotul final de pacienți a fost alcătuit din 205 pacienți de ambele sexe, cu vârste cuprinse între 18 și 76 ani. Datele au fost analizate și prelucrate statistic cu programul Microsoft Excel 2016.

Rezultate. Lotul de studiu a fost compus din 138 pacienți de sex masculin şi 67 pacienți de sex feminin, dintre care 5 bruxomani, 12 respiratori orali, 36 pacienți cu malocluzii şi 54 pacienti care prezentau edentații reduse sau întinse parțial protezate. Indexul gingival Loe şi Silness și indexul de sângerare papilară au avut majoritar valoarea 1. Discuții. În prezentul studiu, cel mai bine au fost reprezentați pacienții tineri. Afecțiunile cardiovasculare au o incidență crescută în rândul lotului analizat, 17,07\% dintre pacienți au declarat că trăiesc în condiții stresante și $47,32 \%$ dintre pacienți au declarat că fumează.

Concluzii. Majoritatea pacientilor din prezentul studiu au fost adulti tineri, cu forme generalizate ale parodontopatiilor. Principalele motive ale prezentării la medic au fost sângerarea gingivală şi halitoza, care constituie semne ale îmbolnăvirii parodontale. Fumatul, stresul cotidian ți bolile cardiovasculare reprezintă factori implicați în apariția și evoluția bolii parodontale.

Cuvinte cheie: gingivită, parodontită, fumat, boli cardiovasculare, stres 


\section{INTRODUCERE}

După Brown şi colab. [1], boala parodontală şi caria dentară sunt cele mai frecvente afecțiuni întâlnite la nivelul dentiției umane. Boala parodontală este o infecție bacteriană cronică ce este caracterizată de inflamație persistentă, afectarea țesuturilor de suport şi resorbția osului alveolar [2].

Termenii de boală parodontală se referă atât la gingivită, cât şi la parodontită [3]. În timp ce gingivita reprezintă o afecțiune reversibilă indusă de prezența plăcii bacteriene, parodontita poate fi definită ca o boală inflamatorie cronică, inițiată de biofilmul dentar şi perpetuată de un răspuns imun dereglat [4].

În general, parodontita este recunoscută drept o afecțiune în care țesuturile de susținere ale dintelui sunt distruse progresiv [5], cu apariția recesiunii gingivale [6], pierderea colagenului gingival [7], degradarea ligamentelor periodontale [8], resorbția alveolelor dentare şi, în final, pierderea dinţilor [9].

Pentru o lungă perioadă de timp, s-a crezut că gingivita şi parodontita apar ca efecte ale îmbătrânirii ligamentelor periodontale, cu creşterea riscului de apariție a inflamației şi a pungilor parodontale [3], dar există studii prin care s-a demonstrat că acest tip de afecțiune nu este doar apanajul adulților, apărând destul de frecvent şi la vârste tinere [10].

\section{SCOP}

Scopul prezentului studiu a fost reprezentat de evaluarea statusului parodontal a unui lot de pacienți și de evidenţierea unor corelații cu factorii favorizanți ai apariției și agravării bolii parodontale.

\section{MATERIALE ŞI METODE}

Studiul s-a desfăşurat în cadrul Clinicii stomatologice „Dr. Vodiță“ pe o perioadă de 2 ani. Lotul de studiu a fost alcătuit inițial din 266 pacienți care s-au adresat Clinicii din diferite motive stomatologice. La lotul iniţial de pacienți am aplicat criterii de includere şi de excludere din studiu. Criteriile de includere în studiu au fost pacienți cooperanți, fără edentații sau cu un număr redus de unități dento-parodontale absente.

Criteriile de excludere din studiu au fost pacienții care au întrerupt tratamentul din diferite motive personale și pacienții cu edentație subtotală sau totală.

După aplicarea criteriilor de includere şi excludere din studiu, lotul final de pacienți a fost alcătuit din 205 pacienți de ambele sexe, cu vârste cuprinse între 18 şi 76 ani.

În vederea includerii în studiul privind evaluarea statusului parodontal, pacienții au semnat consimțământul privind posibilitatea utilizării informațiilor din fișa medicală în scopuri științifice, cu protecția datelor cu caracter personal, şi au efectuat la recomandare ortopantomografii în centre specializate de radiologie dentară în vederea stabilirii exacte a diagnosticului. De asemenea, pacienților li s-au efectuat fotografii încă de la prima prezentare în clinică.

Fiecare pacient inclus în studiu a beneficiat de o anamneză riguroasă, din care s-au cules date privind vârsta pacientului, istoricul medical, istoricul dentar, condițiile de muncă şi viaţă, eventualele obiceiuri vicioase.

Datele au fost analizate şi prelucrate statistic cu programul Microsoft Excel 2016.

\section{REZULTATE}

Lotul de studiu a fost compus din 138 pacienți de sex masculin şi 67 pacienți de sex feminin. În ceea ce priveşte distribuția pe grupe de vârstă, majoritatea pacienților din lotul analizat aparţineau grupei de vârstă 31-40 ani (56,09\%).

În ceea ce priveşte motivele prezentării la medicul stomatolog, pacienții din lotul studiat au enunțat motive precum: sângerare gingivală, leziuni odontale simple şi complicate, tratate sau netratate, restaurări protetice (fractura placajului fizionomic, modificarea de culoare a placajului fizionomic, aspect inestetic ca urmare a retracției gingivale, sensibilitate dureroasă la nivelul stâlpilor de punte sau la nivelul dinților pe care se sprijină elementele de agregare ale protezelor parțiale etc.), halitoză, tulburări funcționale ca urmare a mobilității dentare de diferite grade, depozite de tartru supra şi subgingival, hipersensibilitare dentară.

Principalele motive ale prezentării la medicul dentist au fost reprezentate de sângerarea gingivală şi de halitoză. Astfel, dintre cei 205 pacienți chestionați, 123 au reclamat sângerarea gingivală spontană sau la periaj şi 106 au semnalat prezența 
halitozei. 87 pacienți din total s-au plâns de ambele fenomene.

În ceea ce priveşte condițiile de muncă şi viață, 35 de pacienți au semnalat că lucrează şi/sau trăiesc în condiții stresante. Din totalul de 205 pacienți, 97 sunt fumători (47,31\%), dintre care 28 sunt fumători cronici (reprezentând 28,86\% din rândul fumătorilor şi 13,66\% din lotul de pacienți).

Analizând starea de sănătate generală, 33 de pacienți au declarat că suferă de afecțiuni cardiovasculare, 9 de diabet zaharat (2 prezintă diabet zaharat tip 1 şi 7 diabet zaharat tip 2), 2 pacienți prezintă afecțiuni neurologice (epilepsie) şi 8 prezintă afecțiuni gastro-intestinale (gastrită, ulcer gastro-duodenal, reflux gastro-duodenal). Restul pacienților s-au declarat clinic sănătoşi.

Investigând factorii favorizanți ai îmbolnăvirilor parodontale, la lotul analizat am depistat 5 bruxomani, 12 respiratori orali, 36 pacienți cu malocluzii şi 54 pacienți care prezentau edentaţii reduse sau întinse parţial protezate.

Calculând indexul gingival Loe și Silness, am constatat la lotul studiat o incidență mai crescută a valorilor 1 (102 cazuri) şi 2 (82 cazuri). Valoarea 3 a indexului Loe şi Silness am întâlnit-o în 15 cazuri, iar valoarea 0 în 6 cazuri.

În ceea ce priveşte indexul de sângerare papilară Muhlemann, valoarea 0 am întâlnit-o în 11 cazuri, valoarea 1 în 79 cazuri, valoarea 2 în 72 cazuri, valoarea 3 în 29 cazuri şi valoarea 4 în 14 cazuri.

Pe baza anamnezei, a examenului clinic şi examenului paraclinic imagistic, am stabilit pentru lotul studiat următoarele diagnostice:

- 8 pacienţi nu prezentau semne de îmbolnăvire parodontală (notat cu 1 în figuri)

- 18 pacienți prezentau gingivită cronică localizată (notată cu 2 în figuri)

- 82 pacienți prezentau gingivită cronică generalizată (notată cu 3 în figuri)
- 17 pacienți prezentau parodontită cronică localizată (notată cu 4 în figuri)

- 80 pacienți prezentau parodontită cronică generalizată (notată cu 5 în figuri).

Corelând asocierea dintre sexul pacienților și tipul de boală parodontală diagnosticată, la pacientele din lot am depistat mai frecvent gingivita cronică generalizată (3), iar la bărbați parodontita cronică generalizată (5) (figura 1).

Analizând corelația dintre nivelul declarat de stres, frecvența fumatului și prezența afecțiunilor parodontale în rândul pacienților din lot, am depistat că nefumătorii cu boli parodontale erau majoritari atât în rândul pacienților care nu se considerau stresați, cât și în rândul pacienților care au declarat că trăiau și munceau în condiții stresante (figura 2).

Analizând corelația dintre starea de sănătate generală și prezența bolilor parodontale la lotul studiat, deși lotul analizat conținea în general pacienți clinic sănătoși, pacienții cu parodontită cronică generalizată prezentau asociere cu bolile parodontale și diabet zaharat, iar pacienții cu gingivită cronică localizată prezentau asociere cu diabetul zaharat (figura 3).

La lotul studiat, pacienții cu edentații neprotezate sau cei cu malocluzii erau mai frecvent asociați cu prezența gingivitei și parodontitei cronice generalizate, iar pacienții cu bruxism sau respiratorii orali erau mai frecvenți în rândul cazurilor cu gingivită cronică generalizată (figura 4).

\section{DISCUŢII}

În prezentul studiu, cel mai bine au fost reprezentați pacienții tineri (164 pacienţi sub 40 ani), ceea ce denotă o preocupare a respectivelor grupe de vârstă pentru starea de sănătate dentară.

Din punctul de vedere al istoricului medical, putem afirma că afecțiunile cardiovasculare au o incidență crescută în rândul lotului analizat (33

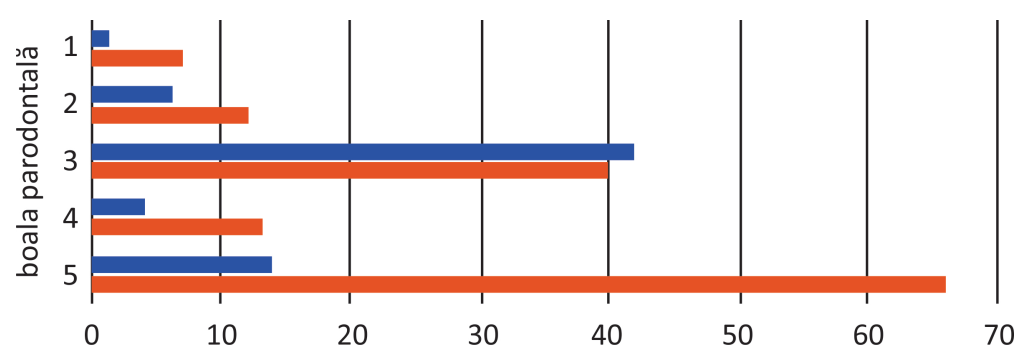

FIGURA 1. Distribuţia afecţiunilor parodontale pe sexe (cu portocaliu reprezentaţi bărbaţii, cu albastru reprezentate femeile) 


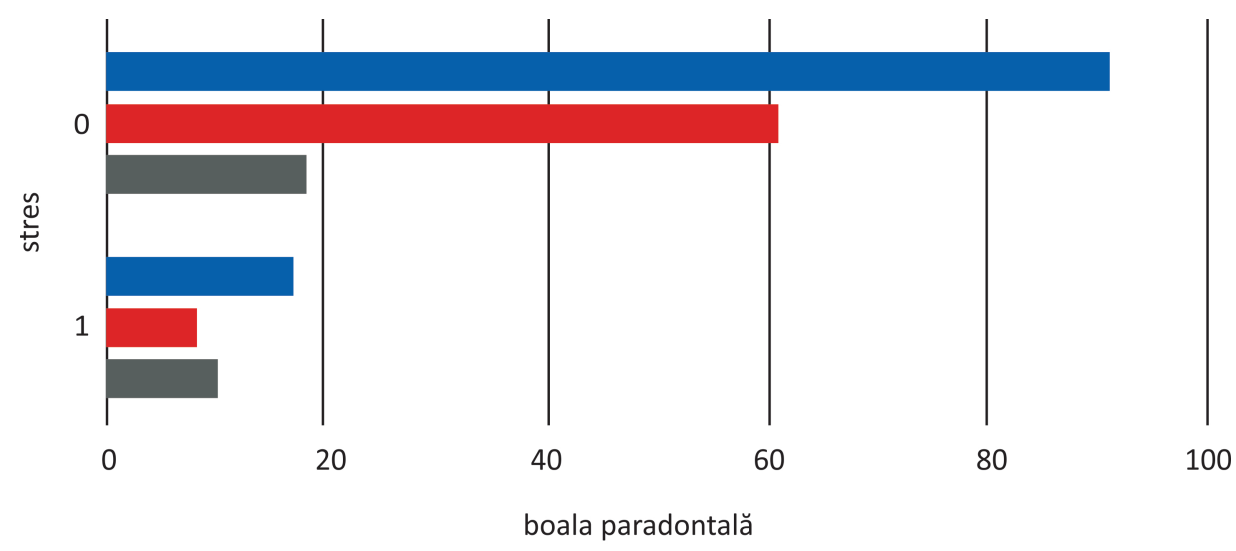

FIGURA 2. Corelaţia dintre stres, fumat şi boala parodontală la lotul studiat ( 0 = albastru, nefumătorii; 1 = portocaliu, fumătorii moderați; 2 = gri, fumătorii cronici)

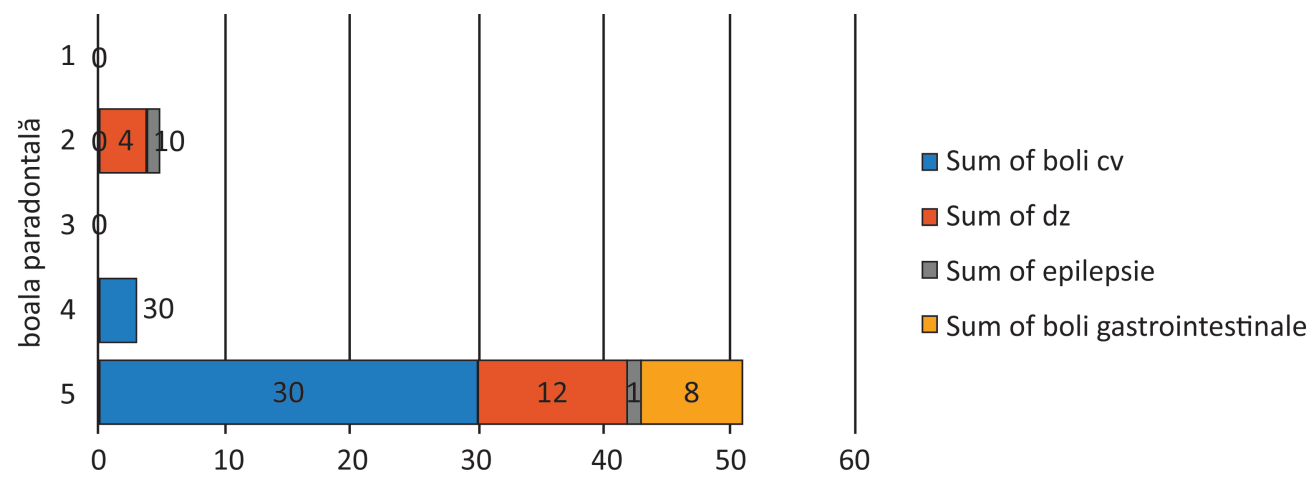

FIGURA 3. Corelaţia dintre starea de sănătate generală şi prezenţa bolilor parodontale

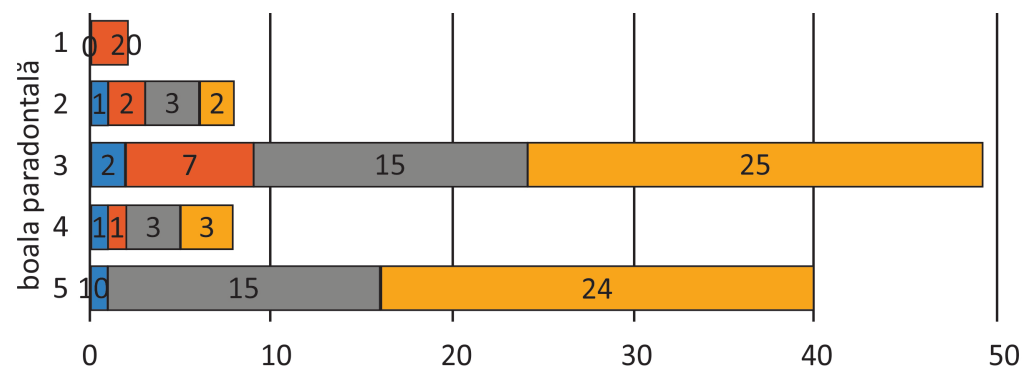

घSum of bruxism $\square$ Sum of respirație orală $\square$ Sum of malocluzii $\square$ Sum of edentații neprotezate

FIGURA 4. Corelaţia dintre factorii orali favorizanţi ai bolilor parodontale şi tipul de boală parodontală depistată

pacienți dintr-un total de 205, reprezentând aproximativ 16,1\%), iar diabeticii au fost prezenți doar în proporție de 4,39\%. Este bine cunoscut caracterul de interdependență dintre boala parodontală şi o serie de patologii sistemice (boli cardiovasculare, diabet zaharat etc.) [11], așa cum am depistat și în studiul nostru.

Evaluarea, întelegerea şi managementul adecvat al factorilor de risc locali şi generali pot facilita prevenirea şi controlul bolii parodontale [12]. Un bun control asupra afecțiunii generale cronice previne instalarea complicațiilor la nivel parodontal.

Asocierea între condițiile stresante de muncă şi viaţă şi alte afecțiuni generale scade capacitatea organismului de vindecare în caz de infecții sau inflamații [13], dar în studiul nostru stresul nu a reprezentat unul dintre factorii asociați în mod frecvent cu apariţia şi agravarea bolii parodontale, din rândul pacienților analizați doar 17,07\% declarând că trăiesc în condiții stresante. 
47.32\% dintre pacienții din prezentul studiu au declarat că fumează, iar riscul de leziuni parodontale în cazul fumătorilor a fost confirmat de multiple studii [14-16]. Se estimează că mai mult de $40 \%$ dintre cazurile de parodontită la adulți se datorează fumatului zilnic [11]. Fumatul interferă cu capacitatea de vindecare parodontală $[17,18]$ după igienizarea mecanică sau după intervenții chirurgicale parodontale sau GBR [19], prin vasoconstricția locală produsă de nicotină. De asemenea, fumatul inhibă funcția imunologică și afectează negativ nivelul imunoglobulinelor, crescând susceptibilitatea la infecții bacteriene.

Este de remarcat prezența la lotul studiat a gingivitei cronice generalizate în $40 \%$ dintre cazuri şi a parodontitei cronice generalizate în 39\% dintre cazurile investigate.

\section{$\overline{\text { BIBLIOGRAFIE }}$}

1. Brown LJ, Brunelle JA, Kingman A. Periodontal status in the United States, 1988-1991: prevalence, extent, and demographic variation. J Dent Res. 1996 Feb;75 Spec No:672-83.

2. Kobayashi R, Kono T, Bolerjack BA, et al. Induction of IL-10producing CD4+ T-cells in chronic periodontitis. Journal of Dental Research. 2011;90(5):653-658.

3. Vargas Segura Al, llyina A, Segura Ceniceros EP, Silva Belmares $Y$, Méndez González L. Etiology and microbiology of periodontal diseases: A review. African Journal of Microbiology Research 2015;9(48):2300-2306.

4. Suvan J, D'Aiuto F, Moles DR, Petrie A, Donos N. Association between overweight/obesity and periodontitis in adults. A systematic review. Obes Rev. 2011 May;12(5):e381-404.

5. Reeves AF, Rees JM, Schiff M, Hujoel P. Total body weight and waist circumference associated with chronic periodontitis among adolescents in the United States. Arch Pediatr Adolesc Med. 2006 Sep;160(9):894-9.

6. Saini R, Saini S, Saini SR. Periodontal diseases: a risk factor to cardiovascular disease. Ann Card Anaesth. 2010 MayAug;13(2):159-61.

7. Leroy R, Eaton KA, Savage A. Methodological issues in epidemiological studies of periodontitis - how can it be improved? BMC Oral Health. 2010 Apr 21;10:8.

8. Bonifait L, Grenier D. Cranberry polyphenols: potential benefits for dental caries and periodontal disease. J Can Dent Assoc. 2010;76:a130.

9. Nesbitt M, Reynolds M, Shiau H, Choe K, Simonsick E, Ferrucci L. Association of periodontitis and metabolic síndrome in the Baltimore Longitudinal Study of Aging. Aging Clin Exp Res. 2010; 22(3):238-242.

10. Escudero-Castaño N, Perea-García MA, Bascones-Martínez A. Revisión de la periodontitis crónica: Evolución y su aplicación

\section{CONCLUZII}

Majoritatea pacienților din prezentul studiu au fost adulți tineri, cu forme generalizate ale parodontopatiilor. Principalele motive ale prezentării la medic au fost sângerarea gingivală şi halitoza, care constituie semne ale îmbolnăvirii parodontale. Fumatul, bolile cardiovasculare, edentațiile neprotezate şi malocluziile au reprezentat la lotul analizat factori favorizanți pentru apariția și evoluția bolii parodontale.

\section{Notă}

Toţi autorii au avut o contribuţie egală la publicarea acestui material.

Conflict of interest: none declared Financial support: none declared

clínica. Avances en Periodoncia e Implantología Oral 2008; 20(1):27-37.

11. Mârţu $S$, Solomon $S$, Potârnichie $O$, Păsărin L, Mârţu $A$, Nicolaiciuc $\mathrm{O}$, Ursarescu I. Evaluation of the prevalence of the periodontal disease versus systemic and local risk factors. International Journal of Medical Dentistry 2013;3(3):212-218.

12. Solomon S, Mârţu A, Ursărescu I, Mârţu S. Severe periodontal impairment in systemic conditions: a case report. Romanian Journal of Oral Rehabilitation 2012;5(2):91-97.

13. Broadbent E, Petrie KJ, Alley PG, Booth RJ. Psychological stress impairs early wound repair following surgery. Psychosom Med. 2003 Sep-Oct;65(5):865-9.

14. Axelsson P, Paulander J, Lindhe J. Relationship between smoking and dental status in 35-, 50-, 65-, and 75-year-old individuals. J Clin Periodontol. 1998 Apr;25(4):297-305.

15. Holm G. Smoking as an additional risk for tooth loss. J Periodontol. 1994 Nov;65(11):996-1001.

16. Martinez-Canut P, Lorca A, Magán R. Smoking and periodontal disease severity. J Clin Periodontol. 1995 Oct;22(10):743-9.

17. Grossi SG, Skrepcinski FB, DeCaro T, Robertson DC, Ho AW, Dunford RG, Genco RJ. Treatment of periodontal disease in diabetics reduces glycated hemoglobin. J Periodontol. 1997 Aug;68(8):713-9.

18. Van der Velden U, Varoufaki A, Hutter JW, Xu L, Timmerman MF, Van Winkelhoff AJ, Loos BG. Effect of smoking and periodontal treatment on the subgingival microflora. J Clin Periodontol. 2003 Jul;30(7):603-10.

19. Tonetti MS. Cigarette smoking and periodontal diseases: etiology and management of disease. Ann Periodontol. 1998 Jul; 3(1):88-101. 